\section{Factors leading to effective teaching of MOOCs}

Effective teaching of MOOCs

\author{
Billy Tak-ming Wong \\ The Open University of Hong Kong, Hong Kong, Hong Kong
}

\begin{abstract}
Purpose - The purpose of this paper is to survey the factors which facilitate effective teaching through massive open online courses (MOOCs).

Design/methodology/approach - A descriptive meta-analysis was conducted to first examine the literature covering the characteristics of teaching in MOOCs, the profile of participants, the instructional design of course materials and/or the course assessment methods - and then to summarise the factors which are conducive to the teaching effectiveness of MOOCs. A random sample of MOOCs was then reviewed to sort out the extent to which the factors can be identified in these courses.

Findings - The factors leading to effective teaching of MOOCs revolve around six areas according to the stages of course delivery, namely, preparation, attraction, participation, interaction, consolidation and post-course support. They address the application of technology to achieve educational purposes, while coping with the potentials and constraints of the MOOC environment. In practice, however, existing MOOCs show varying degrees of the implementation of the factors.
\end{abstract}

Research limitations/implications - As this is an exploratory study summarising and categorising the factors, further work should be done, in particular on the proper adoption of these factors in teaching, their effectiveness and ways of assessing such effectiveness.

Originality/value - The factors identified will help institutions and academics who plan to offer MOOCs to be aware of how teaching can be best delivered to promote effective student learning.

Keywords Massive open online courses (MOOC), Online teaching, Teaching effectiveness

Paper type Research paper

\title{
Introduction
}

In just a few years since their emergence, massive open online courses (MOOCs) have attracted a large number of institutions to offer courses free of charge. The provision of MOOCs allows an institution to reach a much wider range of students from different backgrounds rather than using a traditional mode of teaching.

However, as a relatively new mode of education, there remain many uncertainties for institutions about involving themselves in MOOC provision. An institution which plans to offer MOOCs must answer a key question: How can teaching be delivered effectively in MOOCs?

Despite the benefits that providing MOOCs may offer, some studies have shown that certain aspects of the MOOC environment may be detrimental to effective teaching and learning. For example, the massive scale of MOOCs implies a low instructor-tolearner ratio. As MOOC instructors have to take care of a very large number of students, they can provide little individual attention to each student which may have an adverse effect on their learning outcomes (Hew and Cheung, 2014). Also, the massive information available in the discussion forums for MOOCs may be a hurdle for student

(C) Billy Tak-ming Wong. Published by Emerald Group Publishing Limited. This article is published under the Creative Commons Attribution (CC BY 4.0) licence. Anyone may reproduce, distribute, translate and create derivative works of this article (for both commercial and non-commercial purposes), subject to full attribution to the original publication and authors. The full terms of this licence may be seen at http://creativecommons.org/licences/by/4.0/legalcode

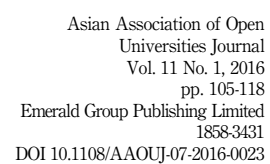


AAOUJ 11,1

learning. As reported in Knox (2014), too many simultaneous discussions and interactions in a MOOC paralyse the participants who attempt to catch up with the key postings and follow the course schedule.

It is therefore important for institutions and academics who intend to offer MOOCs to be aware of how teaching can be best delivered in this new learning environment for effective student learning. This paper addresses this issue by investigating the factors conducive to the effective teaching of MOOCs; and an empirical evaluation is conducted to find out to what extent these factors can be identified in existing MOOCs.

\section{Related studies}

Despite MOOCs having been increasingly offered by institutions and a considerable number of studies relevant to MOOC teaching having been published in recent years, there is a lack of a comprehensive review covering how MOOCs can be effectively delivered. Relevant literature has addressed this issue only weakly. For example, Liyanagunawardena et al. (2013) reviewed the publications related to MOOCs published in 2008-2012, and found that most papers focused only on introducing MOOCs and discussing their challenges. Veletsianos and Shepherdson (2016) investigated the topics of empirical papers on MOOCs published in 2013-2015, which showed that more than 80 per cent of the topics were related to students, such as learner behaviours, performance, learner participation and interaction. Also, Yousef et al. (2014) analysed the research on MOOCs carried out from 2008 to 2014, which revolved around seven dimensions, covering concepts, designs, learning theories, case studies, business models, target groups and assessments. In addition, Gasevic et al. (2014) reviewed the research proposals related to MOOCs and identified nine themes, including social networks and communities, mobile and adaptive learning, motivation and behavioural patterns. These literature reviews, however, do not cover explicitly the factors leading to effective teaching of MOOCs.

The findings of MOOC studies suggest that the teaching of MOOCs may be specific to platforms. Li et al. (2015) presented a comprehensive profiling of 23 representative MOOC platforms covering their various features. For example, the number of learners on these platforms ranged from ten thousand to five million and above; a majority of platforms supported mobile access to their courses; and some platforms had a close relationship with traditional institutions where some MOOCs are recognised by the institutions for credit exemption. Wong (2015) found that the pedagogical orientations of MOOC platforms may influence the courses provided, such as the extensive use of videos on Coursera and edX, and active social interaction on FutureLearn and OpenLearning.

Wong et al. (2015) surveyed the motivations and deterrents for institutions in offering MOOCs. Their findings showed that educational advancement is one major motivation for institutions; and that the implementation of MOOCs in traditional education improved students' learning performance, and helped new students to catch up with their university courses. For the deterrents, uncertainty in enhancing learning performance has been a main concern for institutions, as relevant studies have reported negative findings, such as the lack of instructor support for students in the MOOC environment (Hew and Cheung, 2014); the massive and disorganised information on discussion forums (Knox, 2014); and the lack of learners' self-discipline (Nanfito, 2013).

Similarly, Urrutia et al. (2015) examined institutions' motivations for MOOC development. For example, institutions may like to disseminate knowledge through MOOCs to fulfil the social mission of a higher education institution, or regarded it as a 
strategy for keeping up with higher education evolution. Some institutions were involved in offering MOOCs in order to advance teaching practices, showing their need to keep abreast of developments in this area, in particular those related to ways of effective MOOC delivery.

As a new teaching and learning mode, institutions are required to possess new knowledge and skills so as to obtain desirable teaching and learning outcomes on MOOCs. For example, Sinclair and Kalvala (2015) explored the use of learning analytics to identify MOOC users' level of engagement. The authors suggested that such information would be useful for predicting student dropout. Sinclair et al. (2014) found that conventional types of support services offered to paid MOOC learners, such as small groups and instant academic support from experienced tutors, had attracted only a few dedicated learners to use them.

The present status of MOOC literature reveals that the available studies have not been reviewed systematically and comprehensively to identify the factors related to effective MOOC teaching, although this has been shown to be significant for motivating and informing institutions on MOOC delivery. This paper addresses this issue by surveying these factors from the literature.

\section{Research method}

This study aims to summarise factors reported in the literature for effective MOOC teaching and assess the extent to which the factors can be identified in MOOCs which are currently available. A descriptive meta-analysis was conducted. It first searched and examined the relevant literature from Google Scholar for review and identification of the key factors. The keywords used for searching articles included: "effective teaching and MOOC", "effective MOOC design", "good MOOCs", "peer feedback", and "MOOC assessment". Only the articles reporting empirical studies were included to ensure that the factors were generalised from empirical experience. A total of 35 articles were collected, all of which were published in or after 2010. The factors identified from the studies were categorised following the stages of course delivery from preparatory work before a course began to follow-up work after its completion - that is, it focuses on preparation, attraction, participation, interaction, consolidation and post-course support.

For the assessment of the factors in MOOCs, 32 MOOCs were selected from four platforms: Coursera, edX, FutureLearn and OpenLearning, i.e. eight courses from each platform. The platforms were scanned to identify the subject areas in common and the ongoing courses in each subject area. All the MOOCs selected were taught in English, with all the course materials available. The data were gathered in September 2015. The MOOCs were registered in order to access the teaching and learning resources. Each of them was examined to identify the existence of the factors, if any.

\section{Results}

The following summarises the factors leading to effective teaching of MOOCs at the various stages of course delivery, as reported in relevant studies. The preparation stage involves understanding the various aspects of the development of a MOOC. For attraction, how to draw and arouse the interest of "target learners" in the course is discussed. The emphasis in participation is on the ways to make learners engage in learning activities and interact with the course contents. Interaction centres on encouraging learners to interact with each other to foster learning. In consolidation, the assessment issues are addressed. Finally, post-course support examines monitoring and analysis of student data for the continuous improvement of teaching. 
AAOUJ

11,1

108

\section{Preparation}

Effective teaching of MOOCs starts from a thorough understanding of the MOOC environment, before engaging in course design. Teaching MOOCs is complicated in terms of its "online, open and massive" nature. The wide range of participants might not share the same learning goals (Andersen et al., 2014; Wang and Baker, 2015). Their enrolment is likely to be due to the "openness" feature of MOOCs, which means that not every participant would be equally interested in and committed to learning (Chiappe-Laverde et al., 2015). Particularly for lecture-like xMOOCs, teaching is usually conducted in a one-way approach through videos without knowing how the content has been received by students (Ross et al., 2014). Teaching strategies, expectations and evaluation need to be reengineered in the MOOC context.

Effective teaching is not possible without understanding the perspectives of MOOC learners. Richter and Krishnamurthi (2014) made a number of recommendations for planning a MOOC, among which the first was "to participate in several MOOCs on multiple platforms" (p. 411). Stepping into the MOOC learners' shoes helps to identify and tackle issues that learners may face. Ross et al. (2014) also shared first-hand experience of being learners by enroling in four MOOCs in order to evaluate them.

Not all existing pedagogies are suitable for direct adoption as they were developed before the emergence of MOOCs. Richter and Krishnamurthi (2014) recommend that universities and academics explore new and emerging learning theories related to MOOCs as past theories might be unsuitable for the MOOC context. Also, Ross et al. (2014) stress the importance of context to justify the design of a MOOC, such as the differences between cMOOCs and xMOOCs in pedagogical styles and learning purposes (Daniel, 2012; Yuan et al., 2013).

In considering the topics for MOOC delivery, Richter and Krishnamurthi (2014) recommend choosing ones that the faculty members have expertise in and are passionate about, as this would make the teaching more natural.

Finally, the target audience should be determined in advance. Despite participants on a course being from heterogeneous backgrounds, the learner profiles may vary from course to course in terms of age, country, educational background and so on. For example, for the open course MobiMOOC, the majority of students were 51 to 60 years old (De Waard et al., 2011); but for another course, future of learning, most students were aged from 34 to 44 years (Bremer, 2012). The characteristics of learners should be identified as far as possible to help in designing the MOOCs accordingly.

\section{Attraction}

The first impression of a course has a critical effect on students' decisions to continue studying it or not. Therefore, an effective introduction at the beginning of a course is crucial for drawing students' attention and arousing their interest. Table I summarises ways to attract learners. Given the diverse background of students, it is essential to provide basic information that lays out the principles and prerequisite knowledge early on in the course (DeBoer et al., 2013; Kellogg, 2013). A detail introduction or trailer

\begin{tabular}{lll}
\hline Measure & Benefit & Source \\
\hline Detailed introduction/video trailer & $\begin{array}{l}\text { Provides course information and lays out } \\
\text { instructors' expectations }\end{array}$ & Stacey (2014) \\
Welcoming lecture & & Henshaw (2015)
\end{tabular}

Table I.

Ways to increase attraction 
enables students to know more about the course and the expectations of the instructors (Stacey, 2014). Making use of introductory or welcoming lectures helps to involve students and familiarises them with the course format (Henshaw, 2015).

\section{Participation}

After drawing learners into enroling on a course, measures should be taken to maintain their attention, participation in the course and interaction with others. Table II summarises ways for promoting learners' participation.

It has been widely reported that effective use of multimedia, such as video lectures, audio files and info-graphics, can arouse students' interest, and facilitate their retention and learning (Adamopoulos, 2013; Conole, 2013; Kellogg, 2013). Also, some courses have issued certificates to encourage participation (Bremer and Weiss, 2013) or badges to showcase participation and accomplishments (Bremer, 2012). Although it is not sufficient to rely solely on them, these extrinsic rewards have been found helpful.

In the MOOC environment, interaction with instructors is usually minimal (Nkuyubwatsi, 2013). Reflecting on their MOOC teaching experience, Ross et al. (2014) stated that students were very much concerned about the presences of their instructors from the beginning of a course. To meet this expectation, a live video broadcast was hosted by the instructors, in reaction to which the participants' elation and relief were obvious. Ross et al. (2014) comment that many students were waiting for an embodied, authoritative and recognisable "teacherly moment". This suggests that the presence of teachers in the course promotes students' engagement.

Nkuyubwatsi (2013) suggests various ways in which students can be empowered and their self-confidence built up. For example, getting full scores in quizzes could encourage the less confident students to continue with their learning instead of dropping out. Also, study guides and assignment guides can be provided to support independent learning.

\section{Interaction}

Interaction plays a very important role, particularly in cMOOCs which emphasise social network learning and knowledge creation through interaction. Learners are encouraged to be autonomous and active to take charge of their learning, such as by commenting on others' views. Table III presents ways to enhance interaction.

Social media and online platforms have been widely used to create an engaging environment for interacting. For instance, discussion boards and chat rooms help to guide student conversations about the course materials (Goldberg et al., 2015), and to facilitate peer-to-peer interactions and discussion from students worldwide

\begin{tabular}{lll}
\hline Measure & Benefit & Source \\
\hline $\begin{array}{l}\text { Multimedia (e.g. video lectures, } \\
\text { audio files, } \text { info-graphics) }\end{array}$ & Arouses students' interest & $\begin{array}{l}\text { Adamopoulos (2013), Conole } \\
\text { Certificates or badges for }\end{array}$ \\
$\begin{array}{l}\text { completion of courses } \\
\text { (2013) and Kellogg (2013) }\end{array}$ & Provides an incentive & Bremer (2012)
\end{tabular}
completion of courses Live video broadcast

Satisfies students' need for recognisable Ross et al. (2014) evidence of the teachers' attention

Adequate quizzes, study Empowers and encourages students

Nkuyubwatsi (2013)
Effective teaching of MOOCs
Table II.

Ways to increase participation 
AAOUJ 11,1

\section{0}

Table III.

Ways to enhance interaction
(Murray, 2013). Social networking sites and wikis allow students to build connections with each other and their instructors (Conole, 2013). Bremer (2012) observed that Twitter was the most important communication tool for course participants, beside the course blog. Web-based communication enables instructors to get involved in both one-on-one and group interactions (Kellogg, 2013). DeBoer et al. (2013) found that students who collaborated in their studies performed better than those who worked on their own. Also, Rollag (2010) states that the use of discussion boards may serve as a better means to accomplish the desired learning outcomes for students who do not feel comfortable talking to their instructors face-to-face.

Table IV presents the issues and solutions on interaction. The use of online social media may lead to problems arising from the very large number of diverse students in MOOCs. According to Chen (2014), the huge number of students in MOOCs makes interaction between instructors and students very difficult. Students may also be overwhelmed by the volume of online resources and communication (Kop, 2011; Richter and Krishnamurthi, 2014). If there is not a common knowledge base and educational background among MOOC learners, they can hardly benefit from the discussion (Chen, 2014).

It has been suggested that the presence of instructors in the online learning community may help to alleviate such problems (Richter and Krishnamurthi, 2014; Ross et al., 2014). Discussion boards need to be guided and monitored, otherwise they

\begin{tabular}{|c|c|c|}
\hline Measure & Benefit & Source \\
\hline $\begin{array}{l}\text { Discussion boards, chat } \\
\text { rooms }\end{array}$ & $\begin{array}{l}\text { A platform for discussing teaching } \\
\text { materials } \\
\text { Increases students' performance } \\
\text { Provides another means of interaction }\end{array}$ & $\begin{array}{l}\text { Goldberg et al. (2015) and } \\
\text { Murray (2013) } \\
\text { DeBoer et al. (2013) } \\
\text { Rollag (2010) }\end{array}$ \\
\hline Social networking sites & $\begin{array}{l}\text { Allow the building of connections among } \\
\text { students and teachers }\end{array}$ & $\begin{array}{l}\text { Conole (2013) and Bremer } \\
\text { (2012) }\end{array}$ \\
\hline $\begin{array}{l}\text { Web-based communication } \\
\text { programmes }\end{array}$ & Enables one-on-one interactions & Kellogg (2013) \\
\hline
\end{tabular}

\begin{tabular}{|c|c|c|}
\hline Issue & Solution & Source \\
\hline $\begin{array}{l}\text { Interactions limited by the } \\
\text { enormous enrolments }\end{array}$ & - & $\begin{array}{l}\text { Chen (2014), Richter and } \\
\text { Krishnamurthi (2014) and Kop } \\
\text { (2011) }\end{array}$ \\
\hline $\begin{array}{l}\text { Students valued a strong } \\
\text { instructor presence }\end{array}$ & $\begin{array}{l}\text { Instructors to guide, monitor } \\
\text { and mediate the discussion }\end{array}$ & $\begin{array}{l}\text { Richter and Krishnamurthi } \\
\text { (2014) and Ross et al. (2014) }\end{array}$ \\
\hline $\begin{array}{l}\text { Tension, rudeness, alienation, and } \\
\text { intense debates in discussion } \\
\text { boards }\end{array}$ & boards & $\begin{array}{l}\text { Bali (2014), Milligan et al. (2013) } \\
\text { and Schmidt and McCormick } \\
\text { (2013) }\end{array}$ \\
\hline Liveliness of learning communities & $\begin{array}{l}\text { A team of facilitators to } \\
\text { provide continuous feedback }\end{array}$ & Sánchez-Vera et al. (2015) \\
\hline Better course orientation & $\begin{array}{l}\text { Linking discussion threads to } \\
\text { corresponding course sections }\end{array}$ & Nkuyubwatsi (2013) \\
\hline $\begin{array}{l}\text { Difficulty in forming learning } \\
\text { groups }\end{array}$ & $\begin{array}{l}\text { Curtin Learning Commons } \\
\text { Salmon's five-stage model }\end{array}$ & $\begin{array}{l}\text { Dron and Ostashewski (2015) } \\
\text { Andersen } \text { et al. (2014) }\end{array}$ \\
\hline
\end{tabular}

groups
Goldberg et al. (2015) and

Durray (2013)

Rollag (2010)

(2012)

Kellogg (2013)
Table IV. Issues and solutions regarding interaction 
can easily be derailed into intense debates (Milligan et al., 2013; Schmidt and McCormick, 2013). Instructors can moderate online discussion to avoid tension and rudeness among students in unmediated and unguided discussion (Bali, 2014).

It is also important to maintain the liveliness of the learning community in MOOCs. Particularly for longer courses, few students remain active in online interaction over time (Rodriguez, 2012). Continuous feedback is thus important to encourage participation in the learning community. Sánchez-Vera et al. (2015) reported that a team of ten facilitators was established for a Web Science MOOC, who read all students' comments in the forums and provided responses when needed, while letting students be the drivers of the conversations.

Some specific measures have also been recommended for promoting online interactions. For example, relevant discussion threads could be linked to the corresponding sections in a MOOC to help learners identify easily the threads related to a specific course section (Nkuyubwatsi, 2013). In addition, new learners may encounter difficulties in navigating the online environment at the beginning of a course, and in this case peer support from experienced participants was found helpful (Waite et al., 2013).

It should be noted, however, that bringing learners together online and a learnerfriendly course design might not guarantee interaction. The formation of learning groups is a challenge in MOOCs because of the massive number and wide range of students. Dron and Ostashewski (2015) point out that some elements in conventional learning groups do not exist in MOOCs. For instance, there are normally no leaders, well-established norms and rules of behaviour. The students are not likely to know each other, and there is often no facilitator to moderate interactions. Due to the very large number of students, it is hard for the teacher to provide responsive guidance. Also, as everyone can join and leave a group at any time, it is difficult to build trust among learners. All these factors hinder interaction, collaboration and mutual support in learning. It has been suggested, therefore, that one needs to look "beyond traditional group methodologies in order to capitalise on the social advantage" (p. 58). According to the teachers' experience of EDCMOOC (Ross et al., 2014), e-mails were sent out about two months prior to the start of a course to invite learners to begin making connections with others and prepare for the group interaction in the course.

Some studies have been conducted to address the problems of group interaction in MOOCs. For example, Andersen et al. (2014) analysed and evaluated the nature of collaborative knowledge construction in the discussion forums of a MOOC, covering the actions needed to initiate and facilitate online learning. Following Salmon's five-stage model (5S) (Salmon, 2000), key features were identified. At the first stage, general issues, such as course structure and teacher roles, must be made clear so that students feel safe and secure when using the digital learning platform. At the second and third stages, students learn the use of the platform, such as navigating and sharing information, and are nurtured to show mutual respect, independence/self-confidence and enthusiasm. At the final two stages, the students learn to interact collaboratively by responding to others' posts, giving higher levels of argumentation, constructive critiquing, and challenging others' ideas - and they develop the abilities of self-criticism, a high level of reasoning and reflection. Although MOOC students may not follow these five stages exactly, Andersen et al. (2014) argue that there was a clear progression in showing deeper reflection and engagement in the course.

Another study by Dron and Ostashewski (2015) attempted to build a learning group following phases of first addressing general issues, and then creating a safe and comfortable environment to promote interactions, using the online platform
Effective

teaching of MOOCs 
AAOUJ 11,1

112

"Curtin Learning Commons". For example, the online platform was set to give everyone a sense of control, allowing learners to post freely on it. A wide range of measures were used to support social connection, to help people get to know and trust each other, and to build networks with similar interests. Badges were awarded for learners' activities on the platform to recognise achievement and build a sense of trust.

These studies show that collaborative learning relies on a suitable online environment and students' readiness. It takes time and involves the use of suitable materials to form a learning group and develop interactive and collaborative learning.

\section{Consolidation}

Table V shows ways for enhancing consolidation of course contents. Assessments are important in learning as students have to reflect on, retrieve and apply their learning. Students can also receive feedback for understanding their study progress for improvement. Kulkarni et al. (2015) found that rapid feedback on work in progress in massive classes improved students' learning performance. Yet, assessment is a big challenge for MOOCs, as detailed and timely feedback can hardly be done for the large number of students. In addition, the issue of online cheating has to be resolved (Chen, 2014).

Peer assessment has been common in MOOCs, involving students evaluating the work of their peers with the aid of rubrics or checklists (Sánchez-Vera et al., 2015). Machine grading is also used for closed questions and essays (Sandeen, 2013; Chen, 2014). In addition, some other methods have also been proposed, such as PeerStudio introduced by Kulkarni et al. (2015), in which all students are involved in providing rubric-based feedback on the submissions of their peers. Sánchez-Vera et al. (2015) also proposed a mixed peer assessment approach combining the assessments by peers and experts. Through "decentralising" the work of marking from solely the teacher to different people, this balances the depth and efficiency of feedback in MOOCs.

Authentication is important for the academic integrity of MOOCs. Advanced item analysis techniques have been used to prevent cheating, such as scale-linking and scoreequating (Richter and Krishnamurthi, 2014). Other attempts have been made to verify the identity of students, for instance by offering proctored exams in physical exam centres, webcam proctoring and biometric authentication (Sandeen, 2013; Chen, 2014).

\section{Post-course support}

After rolling out a MOOC, the course and students have to be monitored continuously to identify any issues for improving the course and its teaching. Learning analytics could be used to collect student data (Sánchez-Vera et al., 2015). Kajimoto (2015)

\begin{tabular}{|c|c|c|}
\hline Measure & Benefit & Source \\
\hline Feedback from courseworks & Improves students' learning & Kulkarni et al. (2015) \\
\hline Peer assessment & Alleviates the marking burden & Kulkarni et al. (2015) and \\
\hline Computer-graded questions & of MOOCs instructors & $\begin{array}{l}\text { Sánchez-Vera et al. (2015) } \\
\text { Sandeen (2013) and Chen (2014) }\end{array}$ \\
\hline Scale-linking and score-equating & Prevents cheating & $\begin{array}{l}\text { Richter and Krishnamurthi } \\
\text { (2014) }\end{array}$ \\
\hline $\begin{array}{l}\text { Exam centres, webcam proctoring } \\
\text { and biometric authentication }\end{array}$ & Verify students' identity & Sandeen (2013) and Chen (2014) \\
\hline
\end{tabular}

Table V. Ways to enhance consolidation 
proposed several analyses that could be applied in every MOOC. For example, quantitative analysis could be performed to correlate students' demographic variables and their level of participation. The times and ways in which students viewed the video clips would reflect their learning. Qualitative analysis could be performed by tracking their written communication. Also, observation of the effectiveness of teaching materials for different students can be done to provide insights for improving teaching.

\section{Identification of factors from MOOCs}

Based on the factors summarised from relevant studies, an empirical investigation was conducted to examine the extent to which the factors could be identified from the 32 MOOCs in the sample. The course pages of each MOOC were visited to check for the presence of the factors in the four stages during a course, i.e. attraction, participation, interaction and consolidation.

Figure 1 shows the presence of factors related to attraction found in the courses. All the courses provided a detailed introduction for the students, in the form of text and/or video trailers. Most courses also had welcoming lectures.

Figure 2 presents the presence of factors that promote learners' participation. Almost all courses provided multimedia learning materials, especially video lectures that may be regarded as an essential component of MOOCs. Only one course was found to have no video lectures, but it had some audio files. It is also common to have certificates or badges provided for recognising completion of the tasks in a course, and quizzes or assignments following video lectures. However, only one course was found that provided occasional live chat sessions with the instructor.

Figure 3 shows the presence of factors for facilitating online interaction. Discussion boards were an essential element provided in all courses. Courses in OpenLearning included a browser-based communication tool which allowed real-time chat with instructors or other learners on the courses. The feature to link discussion threads to related course sections was limited by the design of the platform. It was offered in all courses of edX, FutureLearn and OpenLearning, but only some in Coursera. About half of the courses were found to have instructors involved in the online discussion; or a team of facilitators (called "mentors", "teaching staff" or "community TAs") responsible for answering students' enquiries and responding to students' posts, in order to keep the discussion active and updated.
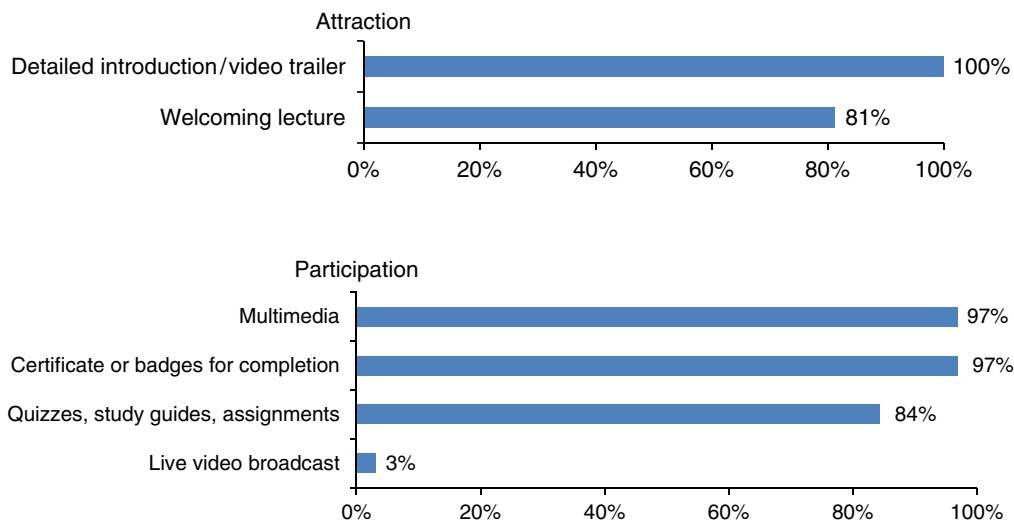

Effective teaching of MOOCs
Figure 1.

Presence of factors in the attraction stage
Figure 2.

Presence of factors in the participation stage 
AAOUJ 11,1

\section{4}

Figure 3.

Presence of factors in the interaction stage

Figure 4.

Presence of factors in the consolidation stage
Figure 4 presents the presence of factors helping learners to consolidate their learning. Computer-graded questions were commonly found among all MOOCs. Coursera was the main platform that emphasised peer assessment. MOOCs that offer examinations at designated centres were uncommon - only one course in FutureLearn was found to offer such a service.

\section{Discussion}

The factors identified from MOOC studies reveal the aspects considered for effective teaching in the MOOC environment. They cover all stages of course development and implementation, showing the significance of features which have been addressed in individual studies. This paper contributes by systematically summarising and categorising these factors, and reporting the extent to which they have been implemented in existing MOOCs.

With the available technology supporting the teaching of massive numbers of students, ways to enhance attraction, participation, interaction and consolidation can be delivered online, such as by video trailers, badges for course completion, social networking sites and computer-graded questions, as found in the studies reviewed. Most of these ways also serve the teaching purposes in the conventional face-to-face mode of educational delivery, such as laying out instructors' expectations in the first lesson, arousing students' interest, and building connections among students and teachers. For these purposes, the effective teaching of MOOCs lies in understanding the special conditions and constraints of online teaching and learning, and making good use of technology as solutions.

Advances in technology also enable new education theories or approaches to be experimented with in the MOOC context. For example, Salmon's (2000) five-stage model was used by Andersen et al. (2014) for facilitating students' online collaboration. This copes with the institutional motivations for MOOC provision as MOOCs have been viewed as a laboratory for educational innovations (e.g. Urrutia et al., 2015; Wong et al., 2015).
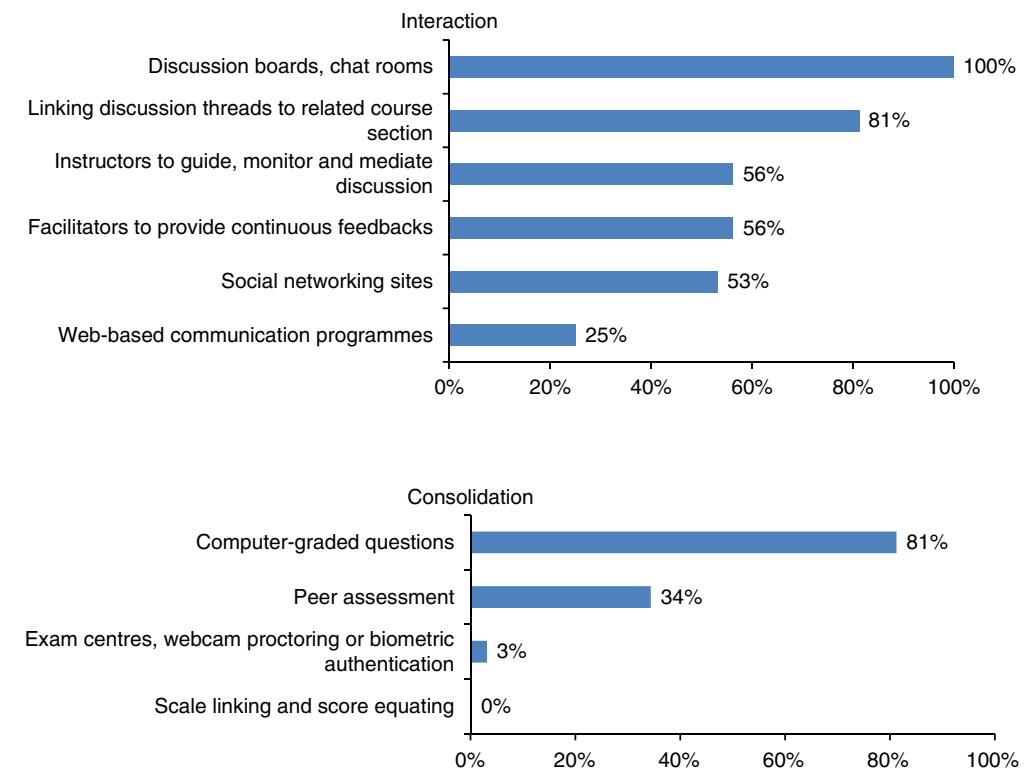
The findings on the existence of the factors in MOOCs show that not all factors reported in the literature have been widely implemented in practice. Especially those requiring more human resources, such as the provision of live video broadcast and feedback to students on social networking sites, were only found in half, or even fewer, of the courses. This may reflect concerns about providing and maintaining a MOOC that involves substantial investment, including the time of teaching and supporting staff (Karnad, 2014; Wong et al., 2015). The current business model that most MOOCs are offered free of charge is facing the challenge of sustainability if the factors of effective MOOC teaching are implemented.

\section{Conclusion}

This paper has presented the factors from the relevant literature leading to effective teaching of MOOCs, and their presence in MOOCs in practice. It contributes to our understanding of the differences between teaching conventional online courses and MOOCs; and the extent to which the ways and approaches proposed in the literature for the teaching of MOOCs were adopted by MOOC providers.

MOOCs are evolving, and so are their student profiles and teaching methods. The present findings do not impose any specific teaching strategy that must be used for effectiveness. The paper serves to direct attention to the MOOC context in various areas, to address practical issues arising from the very large and diverse backgrounds of students that hinder effective teaching. Advances in information and communication technology, as well as openness, make it possible for MOOCs to attract enrolments from around the world. However, without innovations for teacher-student interactions, the concept of openness and desirable teaching and learning outcomes may not be achieved (Chiappe-Laverde et al., 2015). There is no shortcut to effective teaching of MOOC. It is a journey of exploration, experimentation and reflection on different teaching strategies, course design and educational technology.

It is worth noting that there is no evidence that the different features, or a lack of any features in course delivery, would lead to differences in teaching and learning effectiveness (Glance et al., 2013). Given the exploratory nature of this study, further work should be done, in particular on the proper adoption of these features in teaching, their effectiveness and ways of assessing such effectiveness.

\section{References}

Adamopoulos, P. (2013), "What makes a great MOOC? An interdisciplinary analysis of student retention in online courses", paper presented at the 34th International Conference on Information Systems, 15-18 December, Milan.

Andersen, R.K., Garp, K., Nellemann, K., Nielsen, M.F. and Ørngreen, R. (2014), “A framework for the analysis of collaborative and interactive elements in MOOCs", The European Conference on e-Learning, Academic Conferences International Limited, p. 19.

Bali, M. (2014), "MOOC pedagogy: gleaning good practice from existing MOOCs", MERLOT Journal of Online Learning and Teaching, Vol. 10 No. 1, pp. 44-56.

Bremer, C. (2012), "New format for online courses: the open course future of learning", paper presented at the eLearning Baltics (eLBa 2012), Rostock, pp. 63-90.

Bremer, C. and Weiss, D. (2013), "How to analyze participation in a (C)MOOC", paper presented at the International Conference on Education and New Learning Technologies (EDULEARN13), Barcelona, pp. 992-1002. 
AAOUJ 11,1
Chen, Y. (2014), "Investigating MOOCs through blog mining", International Review of Research in Open and Distance Learning, Vol. 15 No. 2, available at: www.irrodl.org/index.php/irrodl/ article/view/1695/2832 (accessed 6 June 2016).

Chiappe-Laverde, A., Hine, N. and Martínez-Silva, J. (2015), "Literature and practice: a critical review of MOOCs/Literatura y práctica: Una revisión crítica acerca de los MOOC", Comunicar, Vol. 22 No. 44, pp. 9-17.

Conole, G. (2013), "MOOCs as disruptive technologies: strategies for enhancing the learner experience and quality of MOOCs", Revista de Educación a Distancia, Vol. 39, pp. 1-17.

Daniel, J. (2012), "Making sense of MOOCs: musings in a maze of myth, paradox and possibility", Journal of Interactive Media in Education, Vol. 2012 No. 3, p.Art. 18.

De Waard, I., Abajian, S., Gallagher, M.S., Hogue, R., Keskin, N., Koutropoulos, A. and Rodriguez, O.C. (2011), "Using mLearning and MOOCs to understand chaos, emergence, and complexity in education", The International Review of Research in Open and Distributed Learning, Vol. 12 No. 7, pp. 94-115.

DeBoer, J., Stump, G.S., Seaton, D. and Breslow, L. (2013), "Diversity in MOOC students' backgrounds and behaviors in relationship to performance in $6.002 \mathrm{x}$ ", paper presented at the Sixth Learning International Networks Consortium Conference, Cambridge, MA.

Dron, J. and Ostashewski, N. (2015), "Seeking connectivist freedom and instructivist safety in a MOOC (En Busca De La Libre Conectividad Y De La Seguridad Instructiva En Un Mooc)”, Educación XX1, Vol. 18 No. 2, pp. 51-76.

Gasevic, D., Kovanovic, V., Joksimovic, S. and Siemens, G. (2014), "Where is research on massive open online courses headed? A data analysis of the MOOC research initiative", The International Review of Research in Open and Distributed Learning, Vol. 15 No. 5, available at: www.irrodl.org/index.php/irrodl/article/view/1954 (accessed 6 June 2016).

Glance, D.G., Forsey, M. and Riley, M. (2013), "The pedagogical foundations of massive open online courses", First Monday, Vol. 18 No. 5, available at: firstmonday.org/ojs/index.php/ $\mathrm{fm} /$ article/view/4350 (accessed 6 June 2016).

Goldberg, L.R., Bell, E., King, C., O’Mara, C., McInerney, F., Robinson, A. and Vickers, J. (2015), "Relationship between participants' level of education and engagement in their completion of the understanding dementia massive open online course", BMC Medical Education, Vol. 15 No. 1, p. 60, available at: bmcmededuc.biomedcentral.com/articles/10.1186/s12909015-0344-z (accessed 6 June 2016).

Henshaw, A. (2015), "How to teach MOOCs effectively", available at: www.campusexplorer.com/ college-advice-tips/F104BF6B/How-to-Teach-MOOCs-Effectively/ (accessed 6 June 2016).

Hew, K.F. and Cheung, W.S. (2014), "Students' and instructors' use of massive open online courses (MOOCs): motivations and challenges", Educational Research Review, Vol. 12, pp. 45-58.

Kajimoto, M. (2015), "MOOC as an all-in-one platform for teaching and research", available at: tl.hku.hk/tag/mooc/ (accessed 6 June 2016).

Karnad, A. (2014), Trends in Educational Technologies, The London School of Economics and Political Science, London, available at: http://eprints.lse.ac.uk/55965/1/_lse.ac.uk_storage_ LIBRARY_Secondary_libfile_shared_repository_Content_Centre $\%$ 20for $\% 20$ Learning $\%$ 20Technology_Trends\%20in\%20Education\%20Technology.pdf (accessed 6 June 2016).

Kellogg, S. (2013), "Online learning: how to make a MOOC", Nature, Vol. 499 No. 7458, pp. 369-371.

Knox, J. (2014), "Digital culture clash: 'massive' education in the e-learning and digital cultures MOOC”, Distance Education, Vol. 35 No. 2, pp. 164-177. 
Kop, R. (2011), "The challenges to connectivist learning on open online networks: learning experiences during a massive open online course", International Review of Research in Open and Distance Learning, Vol. 12 No. 3, available at: www.irrodl.org/index.php/irrod1/ article/view/882 (accessed 6 June 2016).

Kulkarni, C., Bernstein, M.S. and Klemmer, S. (2015), "PeerStudio: rapid peer feedback emphasizes revision and improves performance", paper presented at the Second ACM Conference on Learning@ Scale, 14-18 March, Vancouver, pp. 75-84.

Li, K.C., Wong, B.T.M., Chok, E.W.S. and Lee, T. (2015), "Profiling MOOC platforms: uniformity and diversity in course provision", in Li, K.C. and Yuen, K.S. (Eds), Studies and Practices for Advancement in Open and Distance Education, OUHK Press, Hong Kong, pp. 140-153.

Liyanagunawardena, T., Adams, A. and Williams, S. (2013), "MOOCs: a systematic study of the published literature 2008-2012", The International Review of Research in Open and Distance Learning, Vol. 14 No. 3, pp. 202-227.

Milligan, C., Littlejohn, A. and Margaryan, A. (2013), "Patterns of engagement in connectivist MOOCs", MERLOT Journal of Online Learning and Teaching, Vol. 9 No. 2, available at: http://jolt.merlot.org/vo19no2/milligan_0613.htm (accessed 6 June 2016).

Murray, A. (2013), "Running a MOOC? Massive open online courses", Distance Learning, Vol. 10 No. 2, pp. 11-18.

Nanfito, M. (2013), MOOCs: Opportunities, Impacts, and Challenges - Massive Open Online Courses in Colleges and Universities, CreateSpace Independent Publishing Platform.

Nkuyubwatsi, B. (2013), "Evaluation of massive open online courses (MOOCs) from the learner's perspective", paper presented at the 12th European Conference on e-Learning (ECEL-2013), pp. 340-346.

Richter, S.L. and Krishnamurthi, M. (2014), "Preparing faculty for teaching a MOOC: recommendations from research and experience", International Journal of Information and Education Technology, Vol. 4 No. 5, pp. 411-415.

Rodriguez, C.O. (2012), "MOOCs and the AI-Stanford like courses: two successful and distinct course formats for massive open online courses", European Journal of Open, Distance and E-Learning, available at: www.eurodl.org/?p=current\&article\&article=516 (accessed 6 June 2016).

Rollag, K. (2010), "Teaching business cases online through discussion boards: strategies and best practices", Journal of Management Education, Vol. 34 No. 4, pp. 499-526.

Ross, J., Sinclair, C., Knox, J., Bayne, N. and Macleod, H. (2014), "Teacher experiences and academic identity: the missing components of MOOC pedagogy", Journal of Online Learning and Teaching, Vol. 10 No. 1, p. 57.

Salmon, G. (2000), E-Moderating: The key to Teaching and Learning Online, Kogan Page, London.

Sánchez-Vera, M., del Mar and Prendes-Espinosa, M. (2015), "Beyond objective testing and peer assessment: alternative ways of assessment in MOOCs/Más allá de las pruebas objetivas y la evaluación por pares: Alternativas de evaluación en los MOOC”, Revista de Universidady Sociedad del Conocimiento, Vol. 12 No. 1, pp. 119-129.

Sánchez-Vera, M., León-Urrutia, M. and Davis, H. (2015), "Challenges in the creation, development and implementation of MOOCs: web science course at the University of Southampton/ Desafíos en la creación, desarrollo e implementación de los MOOC: El curso de web science en la universidad de southampton", Comunicar, Vol. 22 No. 44, pp. 37-43.

Sandeen, C. (2013), “Assessment's place in the new MOOC world”, Research \& Practice in Assessment, Vol. 8 No. 1, pp. 5-12. 
AAOUJ 11,1

Schmidt, D.C. and McCormick, Z. (2013), "Producing and delivering a Coursera MOOC on patternoriented software architecture for concurrent and networked software", paper presented at the 2013 companion publication for conference on Systems, programming, \& applications: software for humanity, ACM, pp. 167-176.

Sinclair, J. and Kalvala, S. (2015), "Engagement measures in massive open online courses", in Uden, L., Liberona, D. and Welzer, T. (Eds), Learning Technology for Education in Cloud, Springer International Publishing, pp. 3-15.

Sinclair, J., Boyatt, R., Foss, J. and Rocks, C. (2014), "A tale of tuniwo modes: initial reflections on an innovative MOOC", in Uden, L., Sinclair, J., Tao, Y.-H and Liberona, D. (Eds), Learning Technology for Education in Cloud. MOOC and Big Data, Springer International Publishing, pp. 49-60.

Stacey, P. (2014), "Pedagogy of MOOCs", INNOQUAL-International Journal for Innovation and Quality in Learning, Vol. 2 No. 3, pp. 111-115.

Urrutia, M.L., White, S. and White, S. (2015), "MOOCs in higher education magazines: a content analysis of internal stakeholder perspectives", in Zvacek, S., Restivo, M.T., Uhomoibhi, J. and Helfert, M. (Eds), Computer Supported Education, Springer International Publishing, pp. 395-405.

Veletsianos, G. and Shepherdson, P. (2016), "A systematic analysis and synthesis of the empirical MOOC literature published in 2013-2015", The International Review of Research in Open and Distributed Learning, Vol. 17 No. 2, available at: www.irrodl.org/index.php/irrodl/ article/view/2448/3655 (accessed 6 June 2016).

Waite, M., Mackness, J., Roberts, G. and Lovegrove, E. (2013), "Liminal participants and skilled orienteers: learner participation in a MOOC for new lecturers", MERLOT Journal of Online Learning and Teaching, Vol. 9 No. 2, pp. 200-215.

Wang, Y. and Baker, R. (2015), "Content or platform: why do students complete MOOCs?", Journal of Online Learning and Teaching, Vol. 11 No. 1, pp. 17-30.

Wong, B.T.M. (2015), "Pedagogic orientations of MOOC platforms: influence on course delivery", AAOU Journal, Vol. 10 No. 2, pp. 49-66.

Wong, B.T.M., Li, K.C. and Lam, H. (2015), "Motivations and deterrents to MOOC offerings", in Wong et al. (Eds), Advancing Open and Distance Learning: Research and Practices, OUHK Press, Hong Kong, pp. 16-31.

Yousef, A.M.F., Chatti, M.A., Schroeder, U., Wosnitza, M. and Jakobs, H. (2014), "The state of MOOCs from 2008 to 2014: a critical analysis and future visions", in Zvacek, S., Restivo, M.T., Uhomoibhi, J. and Helfert, M. (Eds), Computer Supported Education, Springer International Publishing, pp. 305-327.

Yuan, L. and Powell, S., Jisc Cetis (2013), "MOOCs and open education: Implications for higher education”, available at: http://publications.cetis.org.uk/wp-content/uploads/2013/03/ MOOCs-and-Open-Education.pdf (accessed 6 June 2016).

\section{Corresponding author}

Billy Tak-ming Wong can be contacted at: tamiwong@ouhk.edu.hk

For instructions on how to order reprints of this article, please visit our website:

www.emeraldgrouppublishing.com/licensing/reprints.htm

Or contact us for further details: permissions@emeraldinsight.com 